\title{
Health-related quality of life: SF-36 based random survey of adults of Peshawar city, Khyber Pakhtunkhwa, Pakistan
}

\section{Ali Raza, Zeinab Hussain, Laila Khan, Kashaf ud Dua Farooq, Arwa tu Zuhra, Saad bin Abi Waqas, Nauman Khattak, Talha Idrees, Mustafa Ahmad, Faisal Wazir, Muhammad Asfandiyar}

Submitted

February 17, 2020

Accepted

March 25, 2020

\section{Author Information}

From: Rehman Medical College, Peshawar, Khyber Pakhtunkhwa, Pakistan

\section{Dr. Ali Raza}

Assistant Professor Department of Community Medicine

(Corresponding Author)

Email: ali.raza@rmi.edu.pk

Zeinab Hussain

Laila Khan

Kashaf ud Dua Farooq

Arwa tu Zuhra

Saad bin Abi Waqas

Nauman Khattak

Talha Idrees

Mustafa Ahmad

Faisal Wazir

Muhammad Asfandiyar

Final Year MBBS Students

Citation: Raza A, Hussain Z, Khan L, Farooq KD, Zuhra A, Waqas SBA, et al. Healthrelated quality of life: SF-36 based survey of adults of district Peshawar city, Khyber Pakhtunkhwa, Pakistan. J Rehman Med Inst. 2020 JanMar;6(1):11-5.

\section{ABSTRACT}

Introduction: Health-related quality of life (HRQOL) is an individual's satisfaction or happiness with the dimensions of life mentioned above, in the context of being affected by or affecting the individual's health. There have been multiple standardized questionnaires developed to evaluate the HRQOL of people, and the 36-item Short Form Health Survey (SF-36) is one of them.

Objective: To assess the health-related quality of life of the general adult population of Peshawar city by use of the SF-36 survey form.

Materials \& methods: A cross-sectional study was conducted in Peshawar city from March to May 2019. The sample comprised of 263 respondents aged 18 and above. Data were collected by systematic random sampling of households using the SF-36 survey form and analyzed using SPSS version 22.

Results: A total of 263 questionnaires were fully filled and valid. Of the $263,66.9 \%$ were male $(\mathrm{n}=176)$ and $33.1 \%$ were female $(\mathrm{n}=87)$. The age of the participants ranged from 18-70 years, with a mean age of $30.5 \pm 11.3$ years. The domain value for SF at 67.78 , followed closely by BP at 67.54 , then $\mathrm{MH}$ at $62.69, \mathrm{PF}$ at $61.27, \mathrm{GH}$ at $60.50, \mathrm{VT}$ at 62.69 , RP at 57.03, and the lowest value was of $\mathrm{RE}$ at 56.52 .

Conclusion: The study revealed that the HRQOL of the population of Peshawar city was less as compared to other international studies. It showed males had a better HRQOL in all domains except one. The HRQOL also declined with increasing age.

Keywords: Quality of Life; Adult; Mental Health; Health Surveys

The authors declared no conflict of interest. All authors contributed substantially to the planning of research, data collection, data analysis, and write-up of the article, and agreed to be accountable for all aspects of the work.

\section{INTRODUCTION}

The definition of health has changed over the decades along with the advancements in healthcare techniques and technology. The current definition of health provided by the constitution of the World Health Organization is a state of complete physical, mental and social well-being and not merely the absence of disease or infirmity. ${ }^{1}$

Health-related quality of life (HRQOL) is an individual's satisfaction or happiness with the dimensions of life mentioned above, in the context of being affected by or affecting the individual's health. It is a broad-ranging concept affected in a complex way by the person's physical health, psychological state, personal beliefs, social relationships and their relationship to salient features of their environment. ${ }^{2}$ There have been multiple standardized questionnaires developed to evaluate the HRQOL of people, and the 36-item Short Form Health Survey (SF-36) is one of them. SF-36 was developed from the Medical Outcomes Study or RAND Health Insurance Experiment. ${ }^{3}$ It is a shorter version of the original 149-question form and is more accurate than the previously designed SF-20 version. ${ }^{4}$ It is a generic tool that can be used to measure the HRQOL of the general population, and not necessarily those specific to any age, disease, or treatment group. ${ }^{5}$ It consists of 36 questions that represent eight health concepts, which are physical functioning (PF), bodily pain (BP), role limitations due to physical health problems (RP), role limitations due to personal or emotional problems (RE), emotional well-being or mental health $(\mathrm{MH})$, social functioning (SF), energy/fatigue or vitality (VT), and general health perceptions (GH). It also includes a single item that provides an indication of perceived change in health.

The SF-36 survey has been used across the world and its validity in different countries and populations has been established in various studies. $^{6-9}$ In Pakistan, there have been multiple studies done using this questionnaire, but they have mostly been focused on groups having a particular disease or affliction, ${ }^{10-12}$ rather than the 
general population of an area. Since SF-36 can be extremely helpful in keeping track of the health of a particular population, the spread of diseases, and outcome of clinical practices and treatments, we can use it to analyze the health of the general public, and proper medical treatments and healthcare can be put forth in order to improve the overall quality of life the population.

The objective of this study was to assess the health-related quality of life of the general adult population of Peshawar city. There has been no similar study done previously on this population.

\section{MATERIALS \& METHODS}

A cross-sectional survey was performed in Peshawar city from March 2019 to May 2019. The sample included people who were aged 18 and above, were residents of Peshawar city and were willing to participate in the study. Data were collected through systematic random sampling of households.

Ethical approval was taken from Research Ethics Committee (REC) of Rehman Medical Institute (RMI). The study participants were explained the purpose of the study and informed consent was taken from the participants.

Every unit from the populous city of Peshawar was included during the data collection procedure. The city of Peshawar was divided into two broad units namely Andar Shehar (the walled city) and Gulbahar Area.

Sample size was calculated as 266 through the WHO formula, using $\mathrm{z}=1.96$, $\mathrm{p}=0.50$, and $\mathrm{e}=0.06$.

Two teams with equal number of forms were created for data collection. A random number of 5 came through lottery and then every 5th household in every street (Mohalla) was used as a sample. Of the 266 forms filled in this way, 3 forms were discarded as they were incomplete.

The RAND 36-Item Short Form Survey (SF-36) was used as the evaluation tool. It consisted of the 36 standard questions, and demographic items were added to the beginning of the questionnaire, including name, sex, age, existing comorbidities, medications taken, exercise status and smoking status.

When the questionnaires were filled and collected, an aggregate percentage score was produced for each of the eight domains measured by SF-36. It was done via a two-step procedure.

Firstly, each of the question responses is related to a different pre-coded numeric value. The response to each question is translated into a raw score from 0 to 100 , with 0 representing a very low-level quality of life (QoL) and 100 depicting a very positive response to the item or a more favorable state of health.

In the second step, these translated item scores were taken and used to determine the score for the eight domains. This was done by adding scores of the items related to a domain and dividing it by the number of items used. For the domain of PF, we added the scores of items no 3, 4, 5, 6, 7, 8, 9, 10, 11 and 12 and divided it by 10. For RP we added scores of items 13, 14, 15 and 16 and divided it by 4 . For RE scores of item 17,18,19 were used, for VT scores of item 23, 27, 29 and 31, for MH scores of items 24, 25, 26, 28 and 30, for SF scores of items 20 and 32, for BP scores of items 21 and 22, and for GH scores of $1,33,34,35$ and 36 were used.

We also calculated Physical Component Summary (PCS) depicting physical QoL by averaging scores of PF, RP, BP and GH, and Mental Component Summary (MCS) representing mental QoL by determining the average of SF, RE, MH and VT.

Data were entered into and analysed via SPSS version 22. Mean was calculated for each of the eight domains, along with standard deviations, for different genders and ages groups. Ttests were done to compare the means of males and females for the domains and the PCS and MCS.

\section{RESULTS}

A total of 263 questionnaires were fully filled and valid. Of the $263,66.9 \%$ were male $(n=176)$ and $33.1 \%$ were female $(n=87)$. The age of the participants ranged from 18 years to 70 years, with a mean age of $30.5 \pm 11.3$ years.

Figure 1 (a-c) shows details of demographic data; 23.2\% ( $n=61)$ of the participants had some type of comorbidity present, including but not limited to diabetes mellitus, hypertension, chronic joint pain, and gastric problems; $13.7 \%(\mathrm{n}=36)$ were smokers while $86.3 \%(n=227)$ were non-smokers; and $47.9 \%$ $(n=126)$ of the participants had regular exercise habits, while the remaining $52.1 \%(\mathrm{n}=137)$ did not partake in regular exercise.
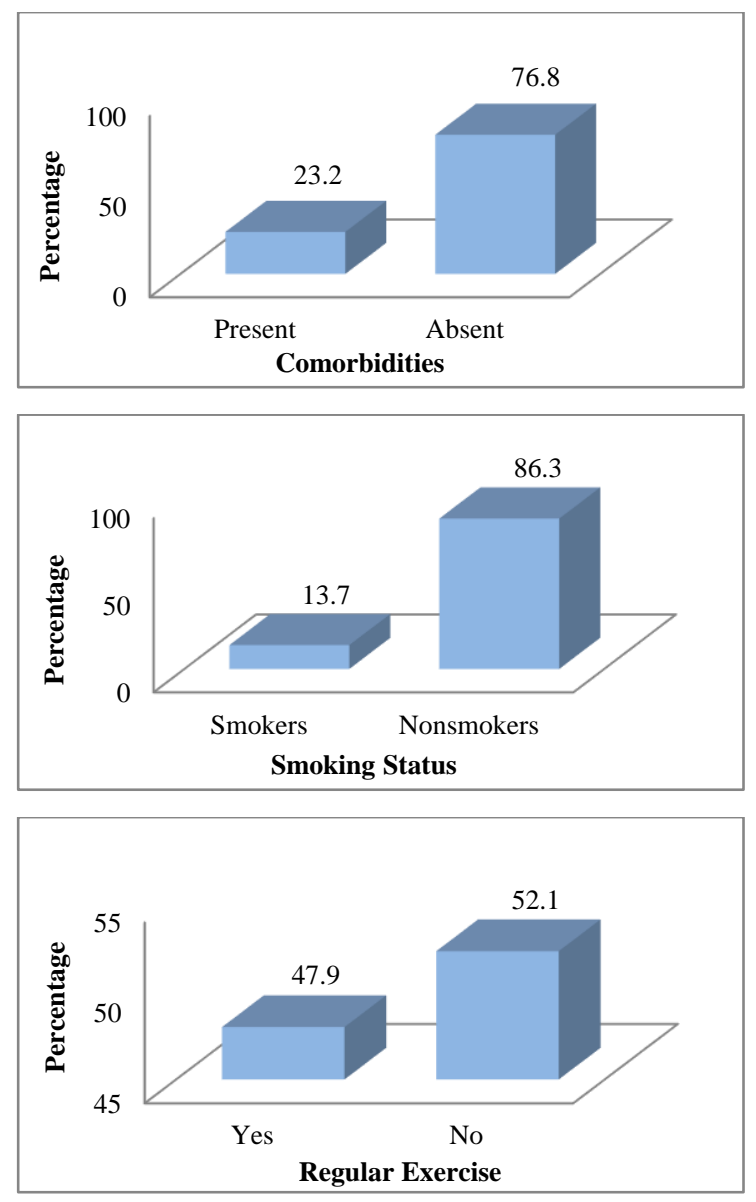

Figure 1(a-c): Demographic data of participants $(n=263)$. 
Table 1 shows the mean value of each domain for the sample, where 100 is the most favorable state of health and zero is the least favorable. The best value was for SF at 67.78 , followed closely by $\mathrm{BP}$ at 67.54 , then $\mathrm{MH}$ at $62.69, \mathrm{PF}$ at $61.27, \mathrm{GH}$ at $60.50, \mathrm{VT}$ at $62.69, \mathrm{RP}$ at 57.03 , and the lowest value was of RE at 56.52 .

\begin{tabular}{|l|c|c|c|c|c|c|c|c|}
\hline \multicolumn{9}{|c|}{ Table 1: Mean of domains of participants (n=263). } \\
\hline Domains & PF & RP & RE & VT & MH & SF & BP & GH \\
\hline \multirow{2}{*}{ Mean values } & $61.27 \pm$ & $57.03 \pm$ & $56.52 \pm$ & $57.98 \pm$ & $62.69 \pm$ & $67.78 \pm$ & $67.54 \pm$ & $60.50 \pm$ \\
& 28.6 & 39.2 & 41.3 & 19.4 & 21.2 & 25.9 & 28.1 & 20.2 \\
\hline
\end{tabular}

Key: PF - Physical Functioning; RP - Role limitations due to Physical health; RE - Role limitations due to Emotional health; VT - Vitality; MH Mental Health; SF - Social Functioning; BP - Bodily Pain; GH - General Health

Table 2 shows the means calculated for the overall Physical Component Summary and Mental Component Summary.

\begin{tabular}{|l|c|c|}
\hline \multicolumn{3}{|c|}{$\begin{array}{l}\text { Table 2: Mean values for overall Physical Component } \\
\text { Summary and Mental Component Summary }(\mathbf{n = 2 6 3}) \text {. }\end{array}$} \\
\hline Domains & PCS & MCS \\
\hline Mean & $61.58 \pm 20.04$ & $61.24 \pm 20.3$ \\
\hline
\end{tabular}

Table 3 shows the means of each domain classified by gender Males had better scores in each of the domains, except in RE (M $=56.44, \mathrm{~F}=56.71)$. After performing t-tests, the difference in male and female quality of life was found to be highly significant $(\mathrm{p}<0.01)$ in the domains of VT, MH, BP, GH, and PCS, and significant $(\mathrm{p}<0.05)$ in MCS.

\begin{tabular}{|c|c|c|c|c|c|c|c|c|c|c|}
\hline \multicolumn{11}{|c|}{ Table 3: Means of domains according to gender $(n=263)$. } \\
\hline Gender & $\mathrm{PF}$ & RP & $\mathrm{RE}$ & VT & MH & SF & $\mathrm{BP}$ & $\mathrm{GH}$ & PCS & MCS \\
\hline Male & $\begin{array}{c}62.41 \pm \\
28.7\end{array}$ & $\begin{array}{c}57.24 \pm \\
36.9\end{array}$ & $\begin{array}{c}56.44 \pm \\
41.8\end{array}$ & $\begin{array}{c}61.39 \pm \\
20.3\end{array}$ & $\begin{array}{c}66.75 \pm \\
21.3\end{array}$ & $\begin{array}{c}67.97 \pm \\
26.3\end{array}$ & $\begin{array}{c}71.93 \pm \\
26.1\end{array}$ & $\begin{array}{c}64.64 \pm \\
19.3\end{array}$ & $\begin{array}{c}64.06 \pm \\
18.4\end{array}$ & $\begin{array}{c}63.14 \pm \\
20.9\end{array}$ \\
\hline Female & $\begin{array}{c}58.97 \pm \\
28.46\end{array}$ & $\begin{array}{c}56.61 \pm \\
43.7\end{array}$ & $\begin{array}{c}56.71 \pm \\
41.9\end{array}$ & $\begin{array}{c}51.09 \pm \\
15.5\end{array}$ & $\begin{array}{c}54.48 \pm \\
18.7\end{array}$ & $\begin{array}{c}67.39 \pm \\
25.1\end{array}$ & $\begin{array}{c}58.65 \pm \\
30.0\end{array}$ & $\begin{array}{c}52.12 \pm \\
19.6\end{array}$ & $\begin{array}{c}56.59 \pm \\
22.2\end{array}$ & $\begin{array}{c}57.42 \pm \\
18.4\end{array}$ \\
\hline p value & 0.359 & 0.902 & 0.961 & $<0.001$ & $<0.001$ & 0.864 & $<0.001$ & $<0.001$ & 0.004 & 0.031 \\
\hline
\end{tabular}

Table 4 shows the means of the domains classified according to gender and age groups. Besides a few exceptions, within both genders, the general trend is that scores decrease with increasing age after 40 .

\begin{tabular}{|c|c|c|c|c|c|c|c|c|c|c|c|c|}
\hline \multicolumn{13}{|c|}{ Table 4: Means of domains and PCS and MCS classified by gender and age group (n=263). } \\
\hline Gender & \multicolumn{2}{|c|}{$\begin{array}{l}\text { Age Group } \\
\text { (Years) }\end{array}$} & PF & RP & RE & VT & MH & SF & BP & GH & PCS & MCS \\
\hline \multirow{5}{*}{ Male } & $18-30$ & Mean & $\begin{array}{c}63.88 \pm \\
28.52\end{array}$ & $\begin{array}{c}58.74 \pm \\
34.95\end{array}$ & $\begin{array}{c}60.19 \pm \\
40.17\end{array}$ & $\begin{array}{c}61.17 \pm \\
19.78\end{array}$ & $\begin{array}{c}66.84 \pm \\
19.46\end{array}$ & $\begin{array}{c}67.35 \pm \\
25.92\end{array}$ & $\begin{array}{c}73.03 \pm \\
25.51\end{array}$ & $\begin{array}{c}65.93 \pm \\
17.62\end{array}$ & $\begin{array}{c}65.40 \pm \\
16.01\end{array}$ & $\begin{array}{c}63.89 \pm \\
19.30\end{array}$ \\
\hline & $31-40$ & Mean & $\begin{array}{c}62.38 \pm \\
30.26\end{array}$ & $\begin{array}{c}61.25 \pm \\
39.61\end{array}$ & $\begin{array}{c}57.50 \pm \\
46.52\end{array}$ & $\begin{array}{c}62.63 \pm \\
24.46\end{array}$ & $\begin{array}{c}67.90 \pm \\
26.28\end{array}$ & $\begin{array}{c}75.00 \pm \\
26.25\end{array}$ & $\begin{array}{c}75.56 \pm \\
29.37 \\
\end{array}$ & $\begin{array}{c}65.41 \pm \\
19.67 \\
\end{array}$ & $\begin{array}{c}66.15 \pm \\
22.04 \\
\end{array}$ & $\begin{array}{c}65.76 \pm \\
26.51 \\
\end{array}$ \\
\hline & $41-50$ & Mean & $\begin{array}{c}62.31 \pm \\
28.54 \\
\end{array}$ & $\begin{array}{c}49.04 \pm \\
39.04 \\
\end{array}$ & $\begin{array}{c}41.03 \pm \\
38.07\end{array}$ & $\begin{array}{c}59.04 \pm \\
17.55 \\
\end{array}$ & $\begin{array}{c}65.54 \pm \\
21.50 \\
\end{array}$ & $\begin{array}{c}62.02 \pm \\
27.95 \\
\end{array}$ & $\begin{array}{c}63.85 \pm \\
25.83 \\
\end{array}$ & $\begin{array}{c}57.31 \pm \\
23.46 \\
\end{array}$ & $\begin{array}{c}58.13 \pm \\
21.54 \\
\end{array}$ & $\begin{array}{c}56.91 \pm \\
17.11 \\
\end{array}$ \\
\hline & $51-60$ & Mean & $\begin{array}{c}47.50 \pm \\
16.58\end{array}$ & $\begin{array}{c}18.75 \pm \\
23.94\end{array}$ & $\begin{array}{c}66.67 \pm \\
38.49\end{array}$ & $\begin{array}{c}63.75 \pm \\
13.15\end{array}$ & $\begin{array}{c}63.00 \pm \\
11.94\end{array}$ & $\begin{array}{c}65.63 \pm \\
15.73\end{array}$ & $\begin{array}{c}70.63 \pm \\
5.15\end{array}$ & $\begin{array}{c}78.75 \pm \\
20.16\end{array}$ & $\begin{array}{c}53.91 \pm \\
12.04\end{array}$ & $\begin{array}{c}64.76 \pm \\
14.85\end{array}$ \\
\hline & $>60$ & Mean & $\begin{array}{c}33.33 \pm \\
17.56 \\
\end{array}$ & $\begin{array}{c}75.00 \pm \\
43.30 \\
\end{array}$ & $\begin{array}{c}33.33 \pm \\
57.74\end{array}$ & $\begin{array}{c}70.00 \pm \\
18.03\end{array}$ & $\begin{array}{c}64.00 \pm \\
32.00\end{array}$ & $\begin{array}{c}50.00 \pm \\
33.07\end{array}$ & $\begin{array}{c}57.50 \pm \\
12.50\end{array}$ & $\begin{array}{c}55.00 \pm \\
20.00\end{array}$ & $\begin{array}{c}55.21 \pm \\
14.66\end{array}$ & $\begin{array}{c}54.33 \pm \\
31.13\end{array}$ \\
\hline \multirow{5}{*}{ Female } & $18-30$ & Mean & $\begin{array}{c}59.22 \pm \\
28.88\end{array}$ & $\begin{array}{c}58.62 \pm \\
40.97\end{array}$ & $\begin{array}{c}57.47 \pm \\
38.39\end{array}$ & $\begin{array}{c}52.67 \pm \\
16.71\end{array}$ & $\begin{array}{c}54.14 \pm \\
18.67\end{array}$ & $\begin{array}{c}65.95 \pm \\
25.41\end{array}$ & $\begin{array}{c}66.29 \pm \\
27.50 \\
\end{array}$ & $\begin{array}{c}54.91 \pm \\
18.00 \\
\end{array}$ & $\begin{array}{c}59.76 \pm \\
21.12 \\
\end{array}$ & $\begin{array}{c}57.56 \pm \\
17.47 \\
\end{array}$ \\
\hline & $31-40$ & Mean & $\begin{array}{c}67.31 \pm \\
22.60\end{array}$ & $\begin{array}{c}50.00 \pm \\
50.00\end{array}$ & $\begin{array}{c}64.10 \pm \\
48.04\end{array}$ & $\begin{array}{c}47.31 \pm \\
08.32\end{array}$ & $\begin{array}{c}52.92 \pm \\
15.76\end{array}$ & $\begin{array}{c}72.12 \pm \\
24.02\end{array}$ & $\begin{array}{c}37.12 \pm \\
28.06\end{array}$ & $\begin{array}{c}46.54 \pm \\
18.97\end{array}$ & $\begin{array}{c}50.24 \pm \\
21.13\end{array}$ & $\begin{array}{c}59.11 \pm \\
17.77\end{array}$ \\
\hline & $41-50$ & Mean & $\begin{array}{c}52.50 \pm \\
34.33\end{array}$ & $\begin{array}{c}59.38 \pm \\
49.89\end{array}$ & $\begin{array}{c}45.83 \pm \\
50.20\end{array}$ & $\begin{array}{c}48.75 \pm \\
19.78\end{array}$ & $\begin{array}{c}54.00 \pm \\
24.66\end{array}$ & $\begin{array}{c}60.94 \pm \\
30.21\end{array}$ & $\begin{array}{c}36.25 \pm \\
24.20\end{array}$ & $\begin{array}{c}51.86 \pm \\
22.19\end{array}$ & $\begin{array}{c}50.00 \pm \\
26.96\end{array}$ & $\begin{array}{c}52.38 \pm \\
25.59\end{array}$ \\
\hline & $51-60$ & Mean & $\begin{array}{c}54.29 \pm \\
28.35\end{array}$ & $\begin{array}{c}57.14 \pm \\
53.45\end{array}$ & $\begin{array}{c}57.14 \pm \\
53.45\end{array}$ & $\begin{array}{c}45.71 \pm \\
09.32\end{array}$ & $\begin{array}{c}57.71 \pm \\
20.38\end{array}$ & $\begin{array}{c}78.57 \pm \\
21.30\end{array}$ & $\begin{array}{c}61.07 \pm \\
35.73\end{array}$ & $\begin{array}{c}35.00 \pm \\
21.60\end{array}$ & $\begin{array}{c}51.88 \pm \\
28.31\end{array}$ & $\begin{array}{c}59.79 \pm \\
22.44\end{array}$ \\
\hline & $>60(n=1)$ & Mean & $20.00 \pm$ & 0 & 0 & $65.00 \pm$ & $76.00 \pm$ & $62.50 \pm$ & $57.50 \pm$ & $85.00 \pm$ & $40.63 \pm$ & $50.88 \pm$ \\
\hline
\end{tabular}

Key: PF - Physical Functioning; RP - Role limitations due to Physical health; RE - Role limitations due to Emotional health; VT - Vitality; MH Mental Health; SF - Social Functioning; BP - Bodily Pain; GH - General Health; PCS - Physical Component Summary; MCS - Mental Component Summary

\section{DISCUSSION}

This study was the first done in Peshawar district about the health-related quality of life of the general population. The overall means of the domains and summary components of the sample population are significantly less than the scores of studies conducted elsewhere in the world, including India, ${ }^{13}$ Canada, ${ }^{14}$ Queensland region of Australia,,${ }^{15}$ China, ${ }^{16}$ and Iran ${ }^{17}$. This could be due to the low utilization of health facilities in Pakistan $^{18}$ as well as lack of awareness of mental health issues ${ }^{19}$. 
Most of the findings in this study are consistent with the results of other studies. There was difference among the sexes within the sample, with males scoring better in all domains and summary components except one. This reinforces the finding that men have a better overall quality of life than women, as has been proven previously in multiple studies using the SF-36 tool. ${ }^{13,14,20-22}$ There could be a number of explanations for this. Research done show that women are more susceptible to depression as compared to men, ${ }^{23}$ which can contribute to a lower score on the mental health domains. It may be that girls experience greater, and/or different, stressors than boys do from adolescence and onwards, when the differing cultural expectations of the two genders become more evident. ${ }^{22}$ Various hormonal reductions like estrogen also causes deleterious health effects in women such as reduction in bone density, cardiovascular diseases, and the like. Non-communicable diseases like cardiovascular diseases, cancers and chronic respiratory diseases strike women at an earlier age in less developed countries. ${ }^{24}$ These could all contribute to the physical health and functionality domains. Another reason for this difference can be men being more physically active in general compared to females, and exercise has a positive impact on HRQOL. ${ }^{25}$

Another trend observed in this study was the decreasing HRQOL with the increase in age, especially after the age bracket of 40. This is in line with other studies performed which showed that health scales, particularly physical health components, corresponded strongly with age. ${ }^{16,26}$ Health generally declines with age due to increased susceptibility to diseases, lower immunity, the manifestation of chronic conditions, and deteriorating mental health. With ageing, there is a loss of muscle strength which in turn results in frailty and it affects the person from living a full, independent life.

\section{LIMITATIONS}

There was a difference in response rate between males and females, resulting in more males than females responding to the questionnaires. As males generally seem to report a better HRQOL, this might have had some influence on the result. We also did not measure income that may contribute on HRQOL. Since the population of Peshawar is so vast, a larger sample size would also have led to more accurate results.

\section{CONCLUSION}

The quality of life of people in the district of Peshawar is mediocre but below average when compared to other researches. On average, men have significantly higher HRQOL scores, which can be explained by sociodemographic and clinical profiles. With progression of age, quality of life scores are reduced.

\section{REFERENCES}

1. World Health Organization (2006) Constitution. Retrieved from https://www.who.int/about/who-weare/constitution

2. Meeberg GA. Quality of life: a concept analysis. J Adv Nurs. 1993 Jan;18(1):32-8.

3. Tarlov AR, Ware JE, Greenfield S, Nelson EC, Perrin E, Zubkoff M. The medical outcomes study: an application of methods for monitoring the results of medical care. J Am Med Assoc. 1989 Aug 18;262(7):925-30

4. McHorney CA, Ware JE, Raczek AE. The MOS 36-Item Short-Form Health Survey (SF-36): II. Psychometric and clinical tests of validity in measuring physical and mental health constructs. Med Care. 1993 Mar;31(3):247-63

5. Ware JE, Sherbourne CD. The MOS 36Item Short-Form Health Survey (SF-36) I. Conceptual framework and item selection. Med Care. 1992; 30:473-83.

6. Bullinger $\mathrm{M}$, Alonso $\mathrm{J}$, Apolone $\mathrm{G}$, Leplège A, Sullivan M, Wood-Dauphinee S, Gandek B, Wagner A, Aaronson N, Bech P, Fukuhara S. Translating health status questionnaires and evaluating their quality: the IQOLA project approach. J Clin Epidemiol. 1998 Nov 1;51(11):91323.

7. McCallum J. The SF-36 in an Australian sample: validating a new, generic health status measure. Aust J Public Health. 1995 Apr;19(2):160-6.

8. Li L, Wang HM, Shen Y. Chinese SF-36 Health Survey: translation, cultural adaptation, validation, and normalisation. J Epidemiol Community Health. 2003 Apr 1;57(4):259-63.

9. Wagner AK, Gandek B, Aaronson NK, Acquadro C, Alonso J, Apolone G, et al. Cross-cultural comparisons of the content of SF-36 translations across 10 countries: results from the IQOLA project. J Clin Epidemiol. 1998 Nov 1;51(11):925-32.

10. Shah AM, Afzal F, Ans M, Asim M, Ayaz S, Niazi SG, et al. Quality of life before and after total knee arthroplasty in clinical settings across Lahore, Pakistan. Pak J Pharm Sci. 2019 Mar;32(2):769-72.

11. Malik M, Nasir R, Hussain A. Health related quality of life among TB patients: question mark on performance of $\mathrm{TB}$ DOTS in Pakistan. J Trop Med. 2018;2018

12. Malik M, Khan A, Hussain A, Hashmi A. Assessment of health-related quality of life among Asthmatic patients: The need for structured pharmaceutical care delivery system in Pakistan. J Pharm Bioallied Sci. 2017 Oct;9(4):272-8.

13. Agrawal R, D'Silva C. Assessment of quality of life in normal individuals using the SF-36 questionnaire. Int J Cur Res Rev. 2017 Feb 1;9(3):43-7.
14. Hopman WM, Towheed T, Anastassiades $\mathrm{T}$, Tenenhouse A, Poliquin S, Berger C, et al. Canadian normative data for the SF-36 health survey. CMAJ. 2000 Aug 8;163(3):265-71.

15. Watson EK, Firman DW, Baade PD, Ring I. Telephone administration of the SF-36 health survey: validation studies and population norms for adults in Queensland. Aust N Z J Public Health. 1996 Aug;20(4):359-63

16. Wang R, Wu C, Zhao Y, Yan X, Ma X, Wu M, et al. Health related quality of life measured by SF-36: a population-based study in Shanghai, China. BMC Public Health. 2008 Dec;8(1):292.

17. Montazeri A, Goshtasebi A, Vahdaninia M, Gandek B. The Short Form Health Survey (SF-36): translation and validation study of the Iranian version. Qual Life Res. 2005 Apr;14(3):875-82.

18. Fatmi Z, Avan BI. Demographic, socioeconomic and environmental determinants of utilisation of antenatal care in a rural setting of Sindh, Pakistan. JPMA. 2002 Apr 1;52(4):138-42

19. Suhail K. A study investigating mental health literacy in Pakistan. J Mental Health. 2005 Apr 1;14(2):167-81.

20. Jenkinson C, Stewart-Brown S, Petersen S, Paice C. Assessment of the SF-36 version 2 in the United Kingdom. J 
Epidemiol Community Health. 1999 Jan 1;53(1):46-50.

21. Doosti-Irani A, Nedjat S, Nedjat S, Cheraghi P, Cheraghi Z. Quality of life in Iranian elderly population using the SF-36 questionnaire: systematic review and meta-analysis. East Mediterr Health J. 2019 Jan 23;24(11):1088-97.

22. Hajian-Tilaki K, Heidari B, Hajian-Tilaki A. Are gender differences in health-related quality of life attributable to sociodemographic characteristics and chronic disease conditions in elderly people? Int J Prev Med. 2017 Nov 7;8:95.

23. Nolen-Hoeksema S. Gender differences in depression. Curr Dir Psychol Sci. 2001 Oct;10(5):173-6.

24. Stevens GA, Mathers CD, Beard JR. Global mortality trends and patterns in older women. Bulletin of the World Health Organization. 2013;91:630-9.
25. Rejeski WJ, Mihalko SL. Physical activity and quality of life in older adults. J Gerontol A Biol Sci Med Sci. 2001 Oct;56 Spec No 2:23-35.

26. Sullivan M, Karlsson J. The Swedish SF36 Health Survey III. Evaluation of criterion-based validity: results from normative population. J Clin Epidemiol. 1998 Nov 1;51(11):1105-13. 